Yüzüncü Yil Üniversitesi
Tarim Bilimleri Dergisi
(YYUJournal of AgriculturalScience)
http://dergipark.gov.tr/yyutbd

Araştırma Makalesi (ResearchArticle)

The Impact of Poultry Production on Empowering of Rural Women Development

\author{
Amal Yasein MOHAMMED ${ }^{1}$, Musa Hago ELFAKI'², Mohamed Ahamed EL HADO ${ }^{3}$ \\ Abdalbasit Adam MARİOD ${ }^{4 *}$ \\ 1,2,3 Department of Agricultural Extension, Faculty of Agricultural Sciences, University of Gezira. \\ ${ }^{4}$ Indigenous Knowledge and Heritage Center, Ghibaish College of Science and Technology, Ghibaish, Sudan. \\ ${ }^{1}$ https://orcid.org/0000-0002-8633-7629 ${ }^{2}$ https://orcid.org/0000-0003-4474-2340 ${ }^{4}$ https://orcid.org/0000-0003-3237-7948 \\ *Correspondingauthor e-mail: basitmario58@gmail.com
}

\section{ArticleInfo}

Received: 03.11.2019

Accepted: 02.03.2020

Online Published 31.03.2020

DOI: $10.29133 /$ yyutbd.641942

\section{Keywords}

Income,

Poultry,

Rural development,

Women empowerment.

\begin{abstract}
In this study forty women were chosen from Gezira state, Sudan to study the effect of the poultry production in their development situation, the samples under study were chosen mainly from Wad Madani town and its adjacent villages. Close-ended questionnaire of 16 questions was developed, and classified to address certain issues. The findings were analyzed using SPSS revealed that, $40 \%$ of the women who raise poultry were in the age limit of 30 39 years, $60 \%$ of them their education level was secondary school or university, which indicates that the level of education was an important factor in women attitudes to adopt poultry production to increase their income and that the majority of the respondents (65\%), were married, $35 \%$ of their farm size was 51100 birds. The study revealed that $57.5 \%$ of the respondents totally depends on poultry production, and that $82.5 \%$ of 40 respondents poultry income contribute in their kid's education, $95 \%$ of 40 respondents poultry income contribute in their family essential needs, and that $92.5 \%$ of 40 respondents poultry income contribute in their family welfare. No significant relationship between the total income from poultry production and the respondent's age, their level of education, and their marital status, was found. Also no significant relationship between the total income from poultry production and the respondent'spoultry contribution in their children education, in the family welfare, and its contribution in the family need was found.
\end{abstract}

\title{
Kümes Hayvanı Üretiminin Kırsaldaki Kadınların Gelişimini Güçlendirmedeki Etkisi
}

\section{Makale Bilgileri}

Geliş: 03.11.2019

Kabul: 02.03.2020

Online Yayınlanma 31.03.2020

DOI:10.29133/yyutbd.641942

\author{
Anahtar kelimeler \\ Gelir, \\ Kümes hayvanları, \\ Kırsal kalkınma, \\ Kadının güçlendirilmesi.
}

Öz: Bu çalışmada, kümes hayvanı üretiminin kadınların gelişme durumundaki etkisini incelemek için, Sudan Gezira eyaletinden, Wad Madani kasabası ve bitişik köylerinden, kırk kadın seçilmiştir. 16 sorudan oluşan yakın uçlu anket geliştirilmiş ve belirli konuları ele almak için sınıflandırılmıştır. Bulgular SPSS kullanılarak analiz edilmiştir. Kümes hayvanı yetiştiren kadınların \% 40'ının 3039 yaş sınırında olduğu; \% 60'ının eğitim seviyesinin ortaöğretim veya üniversite olduğu; bunun eğitim düzeyinin gelirlerini artırmak için kümes hayvanı üretimini benimseme tutumunda önemli bir faktör olduğunu; katılımcıların çoğunluğunun (\% 65) evli olduğu ve çiftliklerinin\% 35'inin 51-100 kümes hayvanına sahip olduğu bulunmuştur. Çalışma, katılımcıların \% 57,5'inin tamamen kümes hayvanı üretimine bağlı olduğunu ve katılımcıların \% 82,5’ininkanatlı geliri ile çocuklarının eğitimine katkıda bulunduğunu; katılımcıların \% 95'inin aile temel ihtiyaçlarına katkıda bulunduğunu ve ankete katılanlardan \%92,5’nin kümes hayvanlarının geliri aile refahına katkıda bulunduğunu göstermiştir. Kanatlı hayvan üretiminden elde edilen toplam gelir ile katılımcının yaşı, eğitim 
düzeyleri ve medeni durumları arasında anlamlı bir ilişki bulunmamıştır. Ayrıca, kümes hayvanı üretiminden elde edilen toplam gelir ile katılımcının çocuklarının eğitimine, aile refahına katkısı ve aile ihtiyacına katkısı arasında anlamlı bir ilişki bulunmamıştır.

\section{Introduction}

Women first initiated agricultural practices and demonstrated the art of science of farming. Women played a key role in the conservation of basic support system (Munmun et al., 2015). Poultry production is a popular activity among rural women in most countries. It can provide meat and eggs for the family, a small and fairly regular source of cash, manure for crop production, feathers, and items for traditional rituals and gifts for friends. Rural women in particular are responsible for half of the world's food production and produce between 60 and 80 percent of the food in most developing countries. Yet, despite their contribution to global food security, women farmers are frequently underestimateld and overlooked in development strategies (FAO, 2008).

Despite their considerable involvement and contribution, women's role in livestock production has often been underestimated or, badly ignored. Livestock species, such as chicken, and poultry are more valuable. Regarding the gender divisions, usually women take care of small animals that live around the house, chicken, and men of the others, goats, buffalos, horses and cattle (Bettencourt et al. 2015). Despite the increasing awareness of the great potentials of women in development, women all over developing countries still face the age-old problems of neglect, inequality, lack of access to productive resources and dependency on men. It is sad to note that despite the level of civilization in the world, gender inequality and disparities between men and women are still prominent in many developing countries. Empowerment is a process in each woman's life but is also a process occurring over time in a society (Golmohammadi, (2018). Yavuz et al. (2018a) determined Turkish women participation rate in agriculture production activities in Northeast Anatolia, they investigated the socio economic and demographic factors which are affecting women participation in agriculture production activities. Their results showed that $31.1 \%$ of respondents are over 51 years old, $51.7 \%$ is primary school graduate, $90.3 \%$ is married and $86.39 \%$ of the women participated in agricultural production. Their results also showed that women are sufficiently participated in agricultural activities. Yavuz et al. (2018b) investigated the role of 360 Turkish rural women in Erzurum, Erzincan and Bayburt provinces in decision making and features affecting the participation to the process. Their results of the study revealed that, being aged, being married and widow, being trained related to profession, being asked their ideas in family affairs, taking part in selling what produced affect the participation to decision making positively, while non-literate bigger farm size and having all income from agriculture affect the participation negatively.

Women in Sudan represent $45 \%$ of the farmers in the irrigated sector and $57 \%$ in rain fed traditional sector, Agricultural production (farm and livestock products) with supplemental resources and substitute resources represent the available resources for the household food consumption in rural Sudan. Income generating activities along with other possible income sources (cash crops, trees products, pension, assets, remittance from migrants, and savings sources) provide household with income to afford foods (Ibnouf, 2009). Poultry rearing at household level has not much enhanced the overall household income yet plays role in contributing to sustain household economy. Besides being healthy and nutritious source of food, it somehow contributes in securing dietary needs especially of the young ones. It has made the women self-employed, more confident, socially empowered and more valued not only in their families but also in their community (Abbas and Zeeshan, 2015). The study aims to study the role of poultry raising in women empowerment, and how it provides additional income for the family, and helps in children education, and welfare of the family.

\section{Materials and Methods}

\subsection{Research design and methodology}

This study was conducted in Gezira state, Wad Madani town, and some villages around (Atra, Eleribab, Fadasi and Um sonut). The target groups in this study were all women. A sample of 40 women 
was selected randomly in Wad Madani town and some village (Atra, Eleribab, Fadasi and Um sonut) round it in Gezira state. Home visits were used as research method. Close-ended questionnaire of 16 questions was developed, and classified to address certain issues. Four questions address the personal characteristic like name, age, level of education, and marital status. One question addresses the source of family income, one for number of family children, question for kind of poultry whether for meat or egg production and one for size of the farm. The questionnaire was pilot tested before dissemination to the women. The findings were analyzed statistically.

\subsection{Statistical analysis}

Data were coded to feed to computer and were analyzed by statistical package for social science (SPSS) for calculation for frequency distribution and simple descriptive statistics and Chi-square test were used to determine some factors affecting.

\section{Results and Discussion}

\subsection{Description of women by personal characteristic and situation}

The purpose of this part is to describe the women in terms of the following characteristics: Age, educational level, marital status, family size, family income, farm size, source of information, how poultry raising income contributes in children education, family needs, and family welfare. Results were tabulated by categories in frequency counts and percentages to show the effect of poultry production among women of Gezira state, Sudan.

\subsubsection{Age}

The women were asked about their age and their answers showed that $40 \%$ of the women who raised poultry were in the age limit of 30-39 years, that is simply because women under this age were economically belong to their families, and also we can say that in the latest few years no enough chances for graduated women to find suitable jobs that suit their qualification while the majority of the respondents being in the age limit of 30-49 years. Chi-square was used to test the association between total income from poultry production and respondents age (Table 1). The table shows that there is nos ignificant relationship between the total income from poultry production and the respondent's age at the probability of 0.05 or less value of 0.629 .

Table 1. Tabulated association level (Chi-Square tests) between total income from poultry production and respondents age.

\begin{tabular}{ccccccc}
\hline \multicolumn{7}{c}{ Age } \\
\hline Income & $20-29$ & $30-39$ & $40-49$ & $50-59$ & $<59$ & Sig.* $^{*}$ \\
\hline$<9,000$ SD & 0.2 & 3.0 & 2.4 & 1.8 & 0.6 & \\
$9,100-15,000 S D$ & 0.2 & 3.0 & 2.4 & 1.8 & 0.6 & 0.629 \\
15100-20,000SD & 0.3 & 3.8 & 3.0 & 2.3 & 0.8 & 1.0 \\
$>$ 20,000SD & 0.4 & 5.3 & 4.2 & 3.2 & & \\
\hline
\end{tabular}

* At significance level of 0.05

\subsubsection{Level of education}

The Women were asked about their level of education and their answers revealed that, more than $62.5 \%$ of the respondent's education level was secondary school or university, which indicates that the level of education was an important factor in women attitudes to adopt poultry production to increase their income, also we can say that in latest few years no enough chances for graduated women to find suitable job that suit their specialization. This also reflects that the adoption of poultry production was increased with the level of education. Chi-square was used to test the association, between total income from poultry production and respondents level of education (Table 2). The table shows that there is no significant 
association between the total income from poultry production and the respondent's education level at the probability level 0.05 or less.

Table 2. Tabulated association level (Chi-Square tests) between total income from poultry production and respondents level of education.

\begin{tabular}{llllllll}
\hline \multicolumn{8}{c}{ Level of education } \\
\hline Income & Literate & Khalwa & $\begin{array}{l}\text { Primary } \\
\text { school }\end{array}$ & $\begin{array}{l}\text { Intermediate } \\
\text { school }\end{array}$ & $\begin{array}{l}\text { Secondary } \\
\text { school }\end{array}$ & University & Sig. \\
\hline$>9$,000SD & 0.4 & 0.2 & 1.2 & 1.0 & 2.6 & 2.6 & 0.062 \\
$9100-15000 \mathrm{~S}$ & 0.4 & 0.2 & 1.0 & 0.9 & 2.3 & 2.3 & \\
$15100-20000$ & 0.6 & 0.3 & 1.7 & 1.4 & 3.6 & 3.6 & \\
\hline
\end{tabular}

\subsubsection{Social status}

The women were asked about their social status and their answers were shown in the table below: Table (3) shows that the majority of the respondents (65\%) were married, while $20 \%$ of the respondents were unmarried and $12.5 \%$ was widow and 2.5 were divorced. This shows how women are willing to share in the household economic because of the economy deterioration that affects the Sudanese life during the last two decades.

Table 3. Tabulated association level (Chi-Square tests) between total income from poultry production and respondents marital status.

\begin{tabular}{lrcccc}
\hline \multicolumn{5}{c}{ Marital status } \\
\hline \multicolumn{1}{c}{ Income } & Married & Divorced & Widow & Unmarried & Sig. \\
\hline$>9,000$ SD & 5.2 & 0.2 & 1.0 & 1.6 & \\
$9,100-15,000$ SD & 5.2 & 0.2 & 1.0 & 1.6 & 0.0159 \\
$15,100-20,000$ SD & 6.5 & 0.7 & 1.3 & 2.0 & \\
$<20,000$ SD & 9.1 & 0.4 & 1.8 & 2.8 & \\
\hline
\end{tabular}

Table (3) shows that, there is no significant relationship between the total income from poultry production and the respondent's marital status at the probability level 0.05 or less.

\subsubsection{Family Size}

The women were asked about the size of their family and their answers were shown by Table (4). Table (4) shows that $42 \%$ of the respondents have 5-7 family members, while $40 \%$ of them have $2-4$ family members and $17.5 \%$ have large family members.

Table 4. Tabulated association level (Chi-Square tests) between total income from poultry production and respondents farm size

\begin{tabular}{llllll}
\hline & \multicolumn{5}{c}{ Farm size/bird } \\
\hline Income & $10-50$ & $51-100$ & $101-200$ & $<200$ & Sig. \\
\hline$>9,000 S D$ & 2.0 & 2.6 & 1.4 & 2.0 & $0.000^{* *}$ \\
$9,000-15,000 S D$ & 2.5 & 3.3 & 1.8 & 2.5 & \\
$15,100-20,000 S D$ & 2.0 & 2.6 & 1.4 & 2.0 & \\
$<20,000 S D$ & 3.5 & 4.6 & 2.4 & 3.5 & \\
\hline
\end{tabular}

Table (4) shows that there is a very highly significant relationship between the total income from poultry production and the respondent farm size at the probability level 0.05 or less.

\subsubsection{Source of income}

The women were asked about their source of income and the following table showed their answers: Table (5) shows that, 37\% of the respondents depend on their own job beside their husband's job 
while $20 \%$ of them depend on other sources of income like donations from their relatives. This is probably because the income earned from their jobs is not enough to meet their needs.

Table 5. Tabulated association level (Chi-Square tests) between total income from poultry production of the respondents and its contribution in their children education.

\begin{tabular}{ccccccc}
\hline & \multicolumn{6}{c}{ Association between total income from poultry production of the respondents and its } \\
contribution in their children education
\end{tabular}

Table 5 shows that there is no significant relationship between total income from poultry production and its contribution in their children education at the probability level 0.05 or less.

\section{1.6. Purpose of poultry raising}

The women were asked about their kind of poultry produce and their answers showed that, all the respondents were raising poultry for egg production this may be for its long egg production cycle and the availability of the consumers.

\subsubsection{Farm Size}

The women were asked about their size of the farm and their answers showed that $35 \%$ of respondents the farm size was from 51 to 100 birds, $27.5 \%$ of respondents the farm size was from 10 to 50 , while $25.0 \%$ of respondents the farm size was more than $200,12.5 \%$ of respondents the farm size was from 101 to 200 bird, this also means that size of the farm depend on the availability of total income to the woman.

\subsubsection{Source of information}

The women were asked about their source of information and their answers revealed that, the majority of the respondents obtained their information from veterinarian extension, and 22.5 of the respondents depend on their own knowledge. A few of them said they obtained their information from their friends and neighbors TV, Newspaper and magazine. None of them obtained their information from radio or research station, although radio is a good media to transfer information.

\subsubsection{Monthly poultry income}

The women were asked about their monthly poultry income and their answers showed that $32 \%$ of the respondents gained more than 20,000 SD, while 25\% gained 15,100-20,000 SD and $22.5 \%$ of the respondents gained 9,100-15,000 SD and 20\% of the respondents gained less than 9,100 SD. This high percentage shows that poultry production is one of the best ways for rural women to gain money.

\subsection{Contribution of poultry in children education, family needs, and family welfare}

\subsubsection{Monthly income other than poultry and poultry raising experience}

The women were asked about their source of monthly income other than poultry and their answers showed that $57.5 \%$ of the respondents totally depend on poultry production as main source of income, $20 \%$ of them gained monthly 9,100-15,000 SD from sources other than poultry, while $10 \%$ gained 15,100-20,000 SD, and 5.0\% gained more than 20,000SD, and 7.5\% gained less than 9,000SD.This showed that the majority of the respondents depend totally on the poultry production as a main source of income. The women were asked about their poultry raising experience and their answers showed that 50\% 
of respondents have more than three years experience in poultry production, while $37.5 \%$ have $1-3$ years, $12.5 \%$ have less than one year. This reveals the interest of women to produce poultry.

\subsubsection{Family children level of education and contribution of poultry in children education}

The women were asked about their children level of education and their answers showed that $42 \%$ of respondents' children were at elementary school level, while $36 \%$ at university and $22 \%$ at secondary school. The women were asked about the contribution of poultry income in children education, and their answers showed that $54.5 \%$ of the respondents poultry income contribute in their children education by $25 \%$ of the total income, and $18.2 \%$ of the respondent poultry production contribute in education by both $50 \%$ and $75 \%$, while $9.1 \%$ of the respondents of poultry production contribute by more than $75 \%$ of the total income their children. This reveals the big role of poultry income in children education. Some of the respondents said that the main purpose of poultry raising is to provide learning their children. Poultry production under the control of rural women, can preferentially benefit them, promoting their empowerment and is also more likely to be used to support their children education (Wong et al. 2017).

\subsubsection{Contribution of poultry production income in family essential needs expenses}

The women were asked about the contribution of poultry income in their essential needs and their answers showed that $52.6 \%$ of the respondents poultry production income contribute in their family essential needs by $25 \%$ of their total income, and $18.4 \%$ of the respondent's poultry production income contribute in their family essential needs by $50 \%$ and $75 \%$ respectively, while only $10.6 \%$ of the respondents of poultry contribute in their family needs by more than $75 \%$. This means that some of respondents depend totally on the income gain from poultry in their essential needs. The total income and family need were shown in Table (6) this table shows that there is no significant relationship, between total income from poultry production, and its contribution in the family need at the probability level 0.05 or less. Fattah (2000) reported that, poultry keeping provides a chance to women for self-employment which may lead her towards income generation and a better standard of living eventually. Poultry is a good source of income for women especially who want to work by staying at their home doing other household chores aside (Fattah, 2000).

Table 6. Tabulated association level (Chi-Square tests) between total income from poultry production of the respondents, and its contribution in their family need expenses

\begin{tabular}{lllllll}
\hline & \multicolumn{7}{c}{ Family need } \\
\hline Income & $25 \%$ & $50 \%$ & $75 \%$ & $<75 \%$ & No contribution & Sig. \\
\hline$<9,000$ SD & 4.0 & 1.4 & 1.2 & 1.2 & 0.2 & 0.442 \\
$9100-15000$ SD & 4.0 & 1.4 & 1.2 & 1.2 & 0.2 & \\
$15100-2000$ SD & 5.0 & 1.8 & 1.5 & 1.5 & 0.3 & 0.4 \\
$<20,000$ SD & 7.0 & 2.4 & 2.1 & 2.1 & 0 & \\
\hline
\end{tabular}

\subsubsection{The contribution of poultry production income in raising family welfare}

The women were asked about the contribution of the income coming from poultry in the family welfare and their answers were showed that $59.5 \%$ of the respondents of poultry producers contribute in their family welfare by $25 \%$ of their total income, and $10.8 \%$ of the respondents of poultry producers contribute in their family welfare by $50 \%$ and $8 \%$ of the respondents of poultry producers contribute in their family welfare by $75 \%$ of their total income, while only $21.6 \%$ of the respondents contribute in their family needs by more than $75 \%$. Table (7) shows that there is no significant relationship, between total income from poultry production, and its contribution in the family welfare at the significance level 0.05 or less. Abbas, and Zeeshan (2015) reported that, poultry keeping made the women self-employed, more confident, socially empowered and more valued not only in their families but also in their community 
Table 7. Tabulated association level (Chi-Square tests) between total income from poultry production of the respondents, and its contribution in their family welfare.

\begin{tabular}{lcrrrrrc}
\hline \multicolumn{1}{c}{ Income } & $25 \%$ & $50 \%$ & $75 \%$ & $<75 \%$ & No contribution & Sig. \\
\hline$<9,000$ SD & 3.8 & 1.0 & 0.8 & 1.4 & 1.0 & 0.503 \\
$9100-15000$ SD & 3.8 & 1.0 & 0.8 & 1.4 & 1.0 & \\
$15100-20000$ SD & 4.8 & 1.3 & 1.0 & 1.8 & 4.8 & \\
$<20,000$ SD & 6.7 & 1.8 & 1.4 & 2.4 & 6.7 & \\
\hline
\end{tabular}

\section{Conclusions}

There is no significant relationship between the total income from poultry production and the respondent's age, their level of education, and their marital status, was found. There no significant relationship between the total income from poultry production and the respondent'spoultry contribution in their children education, in the family welfare, while there is a contribution of poultry raising income in family needs. There is a very highly significant relationship between the total income from poultry production and the respondent farm size.

\section{Acknowledgment}

It has been declared by the corresponding author that the author has no ORCID\# passed away.

\section{References}

Abbas, A., \& Zeeshan M. (2015). Poultry farming: an anthropological take on women empowerment through food security at household level. The Explorer Islamabad"Journal of Social SciencesPakistan, 1, (6), 203-206).

Bettencourt, E. M. V., Tilman, M., Narciso, V., Carvalho, da Silva, M. L., \&Henriques, P. D. S. (2015). The livestock roles in the wellbeing of rural communities of timor-leste. Rev. Econ. Sociol. Rural 53, (1), 63-80.

FAO. (2008). www.fao.org Access date: 21.02.2008

Fattah, K. (2000).Poultry as a Tool in Poverty Eradication and Promotion of Gender Equality.FrandsDolberg and Poul Henning Petersen (eds) Proceedings of a Workshop on Poultry as a Tool in Poverty Eradication and Promotion of Gender Equality.Tune, Denmark .

Golmohammadi, F. (2018). A viewpoint toward Empowering and Entrepreneurship of Rural Women in Iran: Situations and Problems. Black Sea Journal of Public and Social Science 1, (2), 37 - 51.

Ibnouf, F. O. (2009). The role of women in providing and improving household food security in Sudan: implications for reducing hunger and malnutrition. Journal of International Women's Studies 10, (4), 144-167.

Wong, J.T., de Bruyn,J., Bagnol,B., GrieveH., Li,R., Pym M.,\&Alders, R.G. (2017). Small-scale poultry and food security in resource-poor settings: A review,Global Food Security. 15, 43-52

Yavuz, F., Terin, M., Shiwan, M.S., Akay, B., Güler, İ.O, \&Ağsu, K. (2018a). An Analysis on Women Participation in Agricultural Production Activities: Case of Northeast Anatolia TRA1 Region. Turkish Journal of Agricultural Economics 24, (2),185-192.

Yavuz, F., Terin, M., Shiwan, M.S., Akay, B., Güler, İ.O, \&Ağsu, K. (2018b). The Role of Rural Woman In Decision Making in Income Generating Activities: Case of Northeast Anatolia Tra1 Region. International Journal of Economic and Administrative Studies (18 EYİ Private issue)

Munmun, R., Sarker, A., Hoque, M.J. \&Kabir, K.H. (2015). Women's participation in agricultural activities at forest land areas of Bangladesh.Journal of Social Sciences, 11(1), 30-38. 